\title{
The conceptual environment of the frontier discourse in humanities
}

\author{
Lara N. Sinelnikova \\ Academy of Humanities and Pedagogics (branch) \\ of Vernadsky Crimean Federal University in Yalta \\ Yalta, Russia
}

\begin{abstract}
The concept of frontier has been formed for a long time and in different directions. The main characteristics of a frontier - its flexible borders, a zone of space development characterised by uncertainty and instability - have proved their importance for understanding and describing the current state of the environment with regard to its social, cultural, communicative and linguistic indicators. The interdisciplinary (transcendental) potential of a frontier is realised in a complementary combination of natural-scientific and humanitarian scholarship. The aim of the present paper is to justify the scholarly integrity of the term frontier discourse the conceptual milieu of which is created through two overlapping multi-layered phenomena: frontier and discourse. The paper names the vectors of expanding the interdisciplinary possibilities of a frontier under the conditions of a discourse approach. Frontier as a flexible border is presented in the Internet communication, the socio-cultural space of the modern city, in the daily behavioural norms of the elite, in the family relations and in many other conceptual spheres the list of which remains open based on the ontological features of a frontier. Based on the examples from Russian and foreign literature, the author demonstrates the role of the frontier modus in the interpretation of literary texts whose plot, style and images are projected onto national history, culture, mentality in the by-border characteristics. Such frontier features as instability, its ability to create an interaction zone, which, under certain conditions, can lead to integration, are important for understanding the problems of modern language, speech and genre norms. The byborder territory is a place accumulating violations of traditional norms and providing the material which is necessary in order to anticipate the arising norm changes. The transformation of traditional genres and the formation of new ones also take place on frontier territories. It is concluded that frontier discourse ensures the understanding of norm movements in genre-stylistic characteristics.
\end{abstract}

Keywords: frontier, frontier zones, flexible border, by-border, discourse, interdisciplinarity, norm marginalisation, frontier discourse

\section{For citation:}

Sinelnikova, Lara N. The conceptual environment of the frontier discourse in humanities. Russian Journal of Linguistics 24 (2). 467-492. DOI: 10.22363/2687-0088-2020-24$2-467-492$ 
Научная статья

\title{
Концептуальная среда фронтирного дискурса в гуманитарных науках
}

\author{
Л.Н. Синельникова \\ Гуманитарно-педагогическая академия (филиал) \\ Федерального государственного образовательного учреждения \\ «Крымский федеральный университет имени В.И. Вернадского» в г. Ялте \\ Ялта, Россия
}

\begin{abstract}
Аннотация
Концепция фронтира (англ. frontier - граница, рубеж, пограничье) формировалась длительное время и в разных направлениях. Основные характеристики фронтира: подвижная граница, зона освоения пространства, характеризующаяся неопределенностью и неустойчивостью, - обнаружили значимость для понимания и описания актуального состояния среды в ее социальных, культурологических, коммуникационных, языковых показателях. Междисциплинарный (трансдисциплинарный) потенциал фронтира реализуется в комплементарном соположении естественно-научного и гуманитарного знания. Цель статьи - обосновать научную состоятельность понятия фронтирный дискурс, концептуальная среда которого складывается в условиях наложения двух многоуровневых феноменов: дискурса и фронтира. В статье названы векторы расширения междисциплинарных возможностей фронтира в условиях дискурсного подхода. Фронтир как подвижная граница представлен в интернет-коммуникациях, в социально-культурном пространстве современного города, в поведенческих нормах элиты, во внутрисемейных отношениях и многих других концептуальных сферах, список которых, по онтологическим признакам фронтира, принципиально открыт. На примерах из русской и зарубежной литературы показана роль фронтирного модуса в интерпретации художественных текстов, сюжет, стиль и образы которых проектируются на национальную историю, культуру, ментальность в их порубежных характеристиках (By-border characteristics). Такие признаки фронтира, как неустойчивость, способность создавать контактную зону (зону взаимодействия), при определенных условиях ведущую к интеграции, важны для понимания проблемы современной языковой, речевой и жанровой нормы. Территория порубежья (находящегося между) - место сбора нарушений традиционных норм и материал для прогноза нарождающихся изменений нормы. Трансформация традиционных жанров и формирование новых также происходит на фронтирных территориях. Делается вывод, что фронтирный дискурс обеспечивает понимание движения нормы.
\end{abstract}

Ключевые слова: фронтир, фронтирные зоны, подвижная граница, порубежье, дискурс, междисииплинарность, маргинализация нормы, фронтирный дискурс

\section{Для цитирования:}

Синельникова Л.Н. Концептуальная среда фронтирного дискурса в гуманитарных науках // Russian Journal of Linguistics. 2020. T. 24. № 2. C. 467-492. DOI: 10.22363/26870088-2020-24-2-467-492

Фронтир меняет все: методы, привычный образ жизни, социальные отношения, гендерные стереотипы и т.д.

(Якушенков 2019) 


\section{1. Введение. Теоретико-методологические основы исследования}

Термин «фронтир» (англ. frontier - граница, рубеж, пограничье) прошел длинный путь утверждения в научном пространстве от фиксированного значения, связанного с историей Америки по освоению Дикого Запада (концепция американского историка Ф. Дж. Тернера, выдвинутая им в конце XIX в. с такой смысловой доминантой: граница между освоенными и неосвоенными землями, между цивилизацией и дикостью (Turner 1921, Тернер 2009), до стремления разобраться в квалификации фронтира (слово или концепт? [Febvre 1973]) и необходимости установить связь между соположенными терминами, репрезентирующими границу (Ulrich, Троицкий 2019). Метонимическое развитие семантического потенциала всех составляющих термина «фронтир» привело к расширению корпуса номинаций, каждая из которых могла актуализироваться в том или ином аспекте рассмотрения фронтирно организованной информации о мире: край, окраина, обрамление, межа, грань, барьер, линия, барьерная среда, безбарьерная среда, подвижная граница, порубежье, пограничная область, пограничные регионы, пограничный город, пограничный предел, рубеж, маргинальность, линия соприкосновения, линия разграничения, пограничное сознание, пограничная личность, человек (люди) фронтира. Освоение концепта «фронтир» до сих пор происходит в обстановке споров не только относительно терминологии, но и относительно актуальности для современной науки (прежде всего исторической, с которой началось освоение теории фронтира отечественной наукой) (Бостан, Кузнецов 2018). В американистике внимание к историко-цивилизационному аспекту фронтира и его современным проявлениям не прекращается (Billington \& Ridge 1982, Faragher 2006), о чем красноречиво говорит название статьи «Загадки в сравнительном изучении границ: проблемы, некоторые решения и методологические следствия» (Hall 2009).

Аутентичный фронтир как классическое американское понятие (расширение и освоение территорий) на российской почве получил многовекторное развитие и превратился в междисциплинарный концепт, вобравший представление об онтологии границы, граничности, пограничья. Фронтирный дискурс ни в теории фронтира, ни в дискурсологии не был предметом описания. Этот факт, с одной стороны, обеспечивает определенную новизну рассматриваемой в статье проблемы, с другой - порождает ситуацию риска, поскольку ставится задача - обозначить междисциплинарные (трансдисциплинарные - в значении «интеграция методов исследования») связи двух феноменов, каждый из которых имеет не до конца определенный статус. Сеть взаимодействий формируется при понимании фронтира как пространственной реальности и как концепта, а понимание дискурса как способа освоения реальности и превращения ее в текст.

В словарях и энциклопедиях к гуманитарным наукам традиционно относят дисциплины, специализирующиеся на человеке и его жизнедеятельности в обществе. Естественные науки изучают природные явления, внешние 
по отношению к человеку. Постепенно эта дихотомия сходит на нет: новые направления современной науки совмещают природные и социальные факторы на пути к холистическому знанию (экологическая лингвистика, нанопсихология, нанолингвистика, бионика, нейроэкономика, когнитивная экономика, квантовая биология, вычислительная социология и многие другие). Сближение естественно-научного и гуманитарного знания - одно из значимых направлений современной науки. Фронтир, как и дискурс, не вписывается в рамки одной научной дисциплины. Формулировка «Дискурс - объект междисциплинарного изучения» тиражируется в большинстве исследований. Расширение возможностей применения теории фронтира на отечественной почве способствовало появлению «двойных» и «тройных» предметных сфер научного описания: природа и культура; природа, культура и язык; культура, язык и ментальность; ландшафт, экономика и маркетинг; культура и политика. И все это в условиях неустойчивости, подвижности и незавершенности по причине множества социально детерминированных изменений границы и формирования нового пограничья.

Порубежье, с философской точки зрения, — витальная и креативная данность человеческого бытия. «Свойства, присущие состоянию контактного поля, не являются результатом простого суммирования свойств контактирующих объектов. В контактном поле образуются новые свойства, рожденные синтезом свойств контактирующих объектов в условиях взаимодействия» (Забияко 2016: 26). В пределах естественно-научного знания возникают фронтирные зоны гуманитарного направления. Так, география, ориентированная на выявление пространственно-временных закономерностей, развивается во взаимодействии с такими научными областями знания, как когнитивная наука, культурная антропология, культурология, филология, политология, геополитика, политическая география, искусствоведение, история. Гуманитарная география, основоположником которой является Д. Замятин (географ, культуролог, специалист в области когнитивной географии, культурной географии, маркетинга и брендинга территорий, поэт, эссеист), основывается на имажинальной (образной) географии, которая включает мифогеографию, описание в разных жанрах знаковых мест, «наполняемых экзистенциальными смыслами», и многое другое (Замятин 2010).

Ориентируясь, согласно цели статьи, на связь фронтира и дискурса интегрируем их признаки в такую характеристику: фронтирный дискурс основывается на подвижной границе, разделяющей старое и новое и в то же время создающий контактную зону (зону взаимодействия освоенного и осваиваемого, реального и виртуального в их конкуренции), которая определяется как зона пересечения, незаконченности и неопределенности, постепенно ведущая к интеграции (взаимодействию, формируемому на пути к новой норме в ее широком понимании). Специалист в области методологии междисциплинарных исследований М.С. Киселева пишет: «Связывая разнопредметные знания в проективной деятельности, гуманитарная наука обретает новые смыслы, 
которые нуждаются в текстовом выражении. В проективной деятельности соединяются уже имеющиеся знания разных предметных областей для нового гуманитарного междисциплинарного пространства, в котором затем возникают иные исследовательские возможности для каждой из предметных областей дисциплинарного знания» (Киселева 2016: 1166). Это высказывание, по нашему мнению, поддерживает стремление обосновать фронтирный дискурс как проективную междисциплинарную дисциплину.

Концептуальная среда - это место существования изучаемого многомерного объекта, в котором он зарождается, получает развитие и наполняется новым фактическим материалом. Концептуальная среда фронтирного дискурса: 1) формируется на основе взаимодействия внешних и внутренних факторов; 2) изменчива, так как зависит от динамики социальных процессов во всей полноте их проявлений - политических, идеологических, геополитических (глобальных), правовых, социокультурных, экономических, управленческих и др.; 3) фиксирует настоящее, но устремлена в будущее в виде постепенно раскрывающегося потенциала. Бинарный термин фронтирный дискурс означает, что модус границы выводится на уровень дискурса.

Обоснованию содержательной структуры фронтирного дискурса подчинена композиция статьи. Кумулятивная функция фронтирно-дискурсивных исследований проявляется в накоплении сведений по рассматриваемой проблеме (1-й раздел). Фронтир ориентирует не столько на границу как территориально разделяющую линию, сколько на весь историко-культурный процесс, осуществляемый на фронтирных территориях. Этот процесс отражен в художественной литературе, в специфике нарративных реализаций фронтирного показателя в прозе и в поэзии (2-й раздел). Диффузность, открытость и проницаемость - свойства фронтирного дискурса, на фоне которых проявляются не санкционированное нормативными предписаниями употребление языковых средств, нарушение норм жанра и стиля в условиях неустойчивых значений и смыслов (3-й раздел). Выбор тем определяется степенью их актуальности в современном обществе и возможностями применения междисциплинарных методов описания концептуальной среды фронтирного дискурса: дескриптивно-аналитического (толкование социально значимых процессов, формируемых на фронтирных территориях); когнитивно-дискурсивного (взаимодействие текста и контекста); метода социокультурных наблюдений для определения значений и смыслов фронтирного характера.

\section{2. Роль кумулятивности в развитии междисциплинарных знаний и в формировании фронтирного дискурса}

Введение в научное пространство новых объектов в определенной мере объясняется позицией исследователя, настроенного на установление ранее не фиксируемых (или недостаточно фиксируемых) связей между дисциплинарно изучаемыми феноменами. Но главное - наличие условий для предъявления нового знания. Кумулятивный (от латинского cumulare - накоплять, 
усиливать) означает усиление действия через расширение сферы действий. Кумулятивизм (эпистемологическая модель роста научного знания) в рамках фронтирной концепции и в теории дискурса - это не только количественное прибавление знаний о мире, но и свидетельство накапливающихся качественных изменений. Возникающие на фронтирной территории тексты (в широком понимании) могут быть включены в число средств влияния ввиду повышенного внимания субъектов действия к накапливающимся изменениям, желания понять тенденции развития, возникающие в условиях соприсутствия и переплетения семиотических кодов и дискурсов.

Стремление перейти от темы завоевания земель к гуманитарным характеристикам фронтирных территорий было очевидно с самого начала включения концепции фронтира в отечественную науку. Междисциплинарное сетевое издание «Журнал фронтирных исследований» (Journal of Frontier Studies), организованное в 2006 году, включено в Перечень рецензируемых научных изданий по историческим специальностям, но на самом деле в нем публикуется множество статей, соотносимых с дискурсологическими исследованиями широкой квалификации, что соответствует позиции редакции: фронтир - это не только пространство, но прежде всего культурная парадигма, возникающая как реакция на «встречу-с-чужим» - новыми субъектами, новой природной средой, новой культурной или научной парадигмой и т.д. Расширение концептуального поля фронтирного дискурса происходит в разных направлениях.

\section{1. Фронтир интернет-коммуникации}

Киберпространство переполнено разнородной информацией, что напоминает первоначальный хаос, неопределенность и открытость фронтирной территории. «Как некогда фронтир, киберпространство богато - на сей раз не плодородными землями, зверем, лесом и полезными ископаемыми но информацией. И, подобно пионерам фронтира, на новое пограничье отправляются люди. Кого-то ведет жажда знаний, кого-то - непочатый край интересной работы, кого-то — возможность совершать преступления там, куда рука закона еще не дотянулась» (Поволоцкий 2020).

Об интересе политологов к фронтирным свойствам Интернета можно судить по задачам и результатам исследовательского проекта «Фронтир сетевого общества как пространство политического взаимодействия» (Краснодарский государственный университет). В многочисленных публикациях исполнители проекта доказывают, что нарастание нелинейности и неопределенности развития актуализируют фронтирный дискурс в политических коммуникациях. В пространстве сетевого фронтира происходит трансформация политических институтов, накапливаются изменения в политической культуре, формируются новые сообщества и фронтирная идентичность (Морозова, Мирошниченко, Рябченко 2016). Изменения в области политической культуры сказались на языке и стиле политических коммуникаций, 
на речевых особенностях политических текстов разных жанров, на стратегиях и тактиках речевого воздействия. Взгляд лингвиста на рассматриваемые проблемы концентрируется в тезисе: формирование новых сообществ - формирование новых форм и стилей общения.

Транспонируемость тезиса Ф. Тернера о фронтире на цифровой ландшафт очевидна в статьях, авторы которых рассматривают электронное поселенческое пограничье, представляющее собой место для формирования групп по интересам с новыми стилями поведения и пространство для рождения новых мифов (Довбыш 2016, Плотичкина 2018). Герои сетевого фронтира - это не только представители предпринимателей, которые внедрили новые цифровые технологии, основали социальные сети, интернет-торговлю и сумели построить прибыльный бизнес (Плотичкина 2017), но и новые «поселенцы», появление которых обусловлено динамичностью цифрового мира и его возможностями удовлетворять социальные потребности. Героями Сети становятся популярные блогеры (не только люди, но и животные), и блоговедение формируется как проективное междисциплинарное поле, в котором сотрудничают психологи, социологи, культурологи, лингвисты. Незавершенность признаков и характеристик блоготекста позволяет квалифицировать его как фронтирную территорию: происходит освоение нового пространства в условиях подвижной социокультурной среды. Исследуются жанровые и гендерные особенности блогосферы (Herring \& Paolillo 2006, Шляховой 2017), предлагается описание фронтирных территорий как среды отношений бизнеса и власти с акцентом на динамике движения трансформаций при переходе от традиционных официальных моделей отношений к демократическим (Белоконев, Чистов, Пак Джон Кван 2019) и многое другое. Важно, что динамика дискуссий в Сети приобретает ризоматический характер, поскольку переносится на разные сетевые платформы, каждая из которых имеет свой круг пользователей со своими оценочно-языковыми преференциями.

Границы Мнтернета как территории фронтира расширяются, а вместе с этим складывается объемная программа исследования по множеству социально и коммуникативно значимых параметров, поскольку «фронтир киберпространства всегда сохраняет возможность шагнуть дальше «на запад», открывая перспективы «вечного становления информационного общества» (Тузовский 2009: 236).

\section{2. Город как фронтирная среда}

Фронтирное пространство города изучается в разных ракурсах: географическом, историческом, психологическом, философском, лингвокультурологическом, искусствоведческом, политологическом, филологическом. Продолжается традиция описания городских текстов, но уже в условиях новых научных подходов, в том числе - когнитивно-дискурсивном. Объяснительный характер фронтира проявлен в исследовании урбанистических сверхтекстов с географическими объектами. В докторской диссертации 
О.С. Шуруповой «Концептосфера городских сверхтекстов русской литературы: лингвокультурологический аспект» (2017 год) рассматривается концептосфера Петербургского, Московского, Киевского, Ташкентского художественных текстов. В кандидатской диссертации Г.В. Урванцева «Моделирование городского пространства в современном художественном дискурсе» (2018 год) описываются особенности вербальной репрезентации городского пространства в современном британском, американском и русском художественном дискурсе. Обозначен переход «границы» в виде преобразования художественного дискурса в кинематографический.

Трудно переоценить роль такого показателя, как топологические сверхтексты - локусы городов, совмещающие территориальную локальность и внелокальные (расширительные в социокультурном отношении) характеристики. Северный текст, Крымский текст, Калининградский текст, Коломенский текст, Белгородский текст, Воронежский текст и т.д. - это объемные фронтиры, семиотически представленные в единстве географических, исторических, культурных и литературных характеристик. В фундаментальном исследовании В.В. Абашева «Пермь как текст» подчеркивается значимость филологического материала в определении городской идентичности: «Филологические науки, как нам кажется, могут внести в изучение таких сложных социокультурных объектов, как город, особый и, возможно, генерализующий вклад. Прежде всего потому, что все процессы, сопровождающие жизнь города (экономические, природные, социальные), приводят к знаковым отложениям в языке, и зачастую только по следам в языке становятся доступными для наблюдения» (Абашев 2000:14). Особое внимание В.В. Абашев уделил творчеству Б.Л. Пастернака, для которого характерна повышенная чувствительность к пространству и его границам, произведениям В.В. Каменского и ряда современных поэтов, для которых Пермь была географически и эстетически значимой.

Современный город - иллюстрация фронтира как движущейся границы. Фронтирная гетеротопия - наличие в городе множества контактирующих друг с другом пространств (Романова 2016) - проявляет как устойчивость, так и изменчивость: происходит перемещение границ между центром и окраинами, между старой и новой частями города, то есть образуются многие «другие пространства». При этом важно, что фронтирные характеристики влияют на особенности социального взаимодействия в пространстве города, фиксируют совместность или раздельность норм и ценностей разных слоев городского общества, оказывают влияние на формирование интегрированной идентичности. Особенно важен учет фактора фронтирных территорий в поликультурном городском пространстве: в результате соприкосновения культур и языков формируются зоны интеграции, в значительной степени определяющие региональную языковую картину мира. Подвижна концептосфера современного города. Пример - слово «реновация» (лат. renovatio обновление, возобновление, ремонт, то есть процесс улучшения структуры), 
вошедшее в топ-20 популярных слов года в соцмедиа в 2017 году (вместе со словами хайn, харассмент, токсичный и др.). Слово внесло изменение в «ментальную карту» Москвы и вошло в описание словесного портрета города.

В контексте фронтирной урбанистики особое место занимают города с экстремальными природными условиями (северный фронтир, арктический фронтир) и повышенной степенью миграции. Например, Норильск (Замятина 2007) - город с объемным бэкграундом, включающим прошлое, настоящее и будущее. Прошлое связано с Норильлагом (ГУЛАГ в Норильске) и с именем заключенного Льва Гумилева — археолога, географа, историка, этнолога, писателя и переводчика, создателя пассионарной теории этногенеза. Исторический факт пребывания Льва Гумилева в городе способствовал созданию «образа территории». Проект «Гумилевские дни в Норильске», разработанный совместно с Музеем Анны Ахматовой в Фонтанном доме (Санкт-Петербург), можно считать культурной реализацией фронтира - встречей городов на основе общей памяти о времени и о знаковых именах. «Музей изначально является пространством пересечений множества пограничий: между настоящим и прошлым, между посетителем и экспонатом, между реальной жизнью и музейной экспозицией» (Гринько 2016).

В новых социально-экономических условиях территориальная идентичность соотносится с расширенным восприятием города, его миссией в широком культурно-экономическом и политическом пространстве. Но у каждого человека есть и личное пространство в городе, что отражено во множестве воспоминаний, вошедших в сюжеты мемуарно-художественной литературы, очерковой публицистики и в биографически отмеченные стихотворения.

\section{3. Элита и фронтир}

Политическая элита, административная элита, интеллектуальная элита, научная элита, региональная элита, тусовочная элита - это разные поведенческие нормы и формы самопрезентации, градуируемые по шкале: «мы/они» как одном из фронтирных (разграничительных) показателей. Каждая из сторон маркирует свои ценности в коммуникации, в риторической организации текстов, в выборе оценочных коннотаций. Отсюда естественно рассмотрение дискурса элиты в синергетической парадигме (Островская 2016). В перечень дискурсообразующих концептов элиты входят: избранность, власть, публичность, закрытость, социальная значимость, привилегии, политическое влияние, компетентность, профессионализм, ответственность, успех, материальное благосостояние, нравственность, сохранение традиций, целеустремленность, космополитизм, люмпенизация, роскошь, рациональность, снобизм, харизматичность, свобода, интеллигентность. Каждый элемент этого ряда актуализируется типологически и (или) ситуативно, эксплицитно или имплицитно, но в любом случае аспектное пространство элитарности 
оценивается с двух сторон: со стороны самих представителей элиты и со стороны общества, и эти два вида оценки могут существенно отличаться на текстовом уровне.

В статье «Элита и фронтир» П.Л. Карабущенко пишет: «Фронтир весьма распространенное явление, которое мы можем встретить в своей повседневности везде, где возникают структурные разрывы в системе. <..> Было замечено, что элиты ведут себя совершенно иначе, когда оказываются в пограничной ситуации (в критической точке)» (Карабущенко 2016: 92). На наш взгляд, «критической точкой» есть основания считать разрыв границы между декларируемым статусом и реальным поведением, в том числе речевым, находящимся в состоянии размытых границ в отношении к норме, ориентирующей на элитарный тип речевой культуры. Традиционно считалось, что массовая и элитарная культура располагаются на разных территориях по критериям распространенности, общедоступности, развитому вкусу. В современных условиях массовая культура становится культурой повседневности. Не случайно профессор О.Б. Сиротинина, представившая в начале XXI века речевой портрет элитарной языковой личности (полноценное владение нормами литературного языка, уместное применение его стилей, понимание различий между письменной и устной речью, следование этическим нормам общения), через 15 лет обратила особое внимание на факторы экологической рискогенности, прежде всего на недопустимость снятия ограничений на употребление обсценной, грубой и нелитературной лексики (Сиротинина 2014). Именно на речевом уровне отмечается нейтрализация границы между элитарной речевой культурой, среднелитературной, фамильярноразговорной и даже просторечно-жаргонной. В популярной социальной сети Вконтакте встретилась просьба: Умоляю, расскажите мне об ЭЛИТАРНОМ ТИПЕ РЕЧЕВОЙ КУЛЬТУРЫ. Меня интересует всё, что Вы можете рассказать о Нём (оформление просителя).

\section{4. Гастрономический фронтир и глюттонический дискурс}

Фронтирность гастрономических практик (Яковлева 2018) - это привнесение других в гастрономическое пространство, то есть нарушение границ с возможной последующей интеграцией своего и чужого. В научное пространство термин «глюттония» (от латинского gluttire - nоглощуать, nроглатьвать) был введен профессором А.В. Оляничем и получил комплекс лингвосемиотических и лингвокультурологических характеристик в русле концепции презентационного дискурса (Олянич 2004). О расширении границ исследования глюттонического дискурса можно судить по содержанию кандидатской диссертации М.В. Ундрицевой «Глюттонический дискурс: лингвокультурологические, когнитивно-прагматические и переводческие аспекты (на материале русского, английского, французского и греческого языков)» (2015 год). В диссертации феномен еды рассмотрен как национальный культурный код, манифестируемый во множестве разножанровых текстов - 
художественных, презентационно-рекламных, связанных с рецептурной активностью, гастрономическим блогерством, ресторанным бизнесом и т.д. Фронтир и современный глюттонический дискурс связаны по признаку пространственной открытости, возможности освоения новых гастрономических культур через Сеть, через гастрономический туризм и даже через художественный нарратив, в который включаются кулинарные рецепты (например: Лаура Эскивель, Шоколад на крутом кипятке; Кристин Хармель, Забвение пахнет корицей).

История еды - история жизни любого народа (Fernandez-Armesto 2002, Wrangham 2009). Широкий междисциплинарный подход в описании гастрономического кода и повседневных практик представлен в монографии И.В. Сохань «Трансформации современной гастрономической культуры и тоталитет фастфуда» (Сохань 2014). На множестве примеров автор доказывает, что гастрономические практики формируют образ жизни и выступают в роли маркеров многих социальных процессов, влияют на гендерные (прежде всего - семейные) отношения, выявляют связь еды и власти, определяют стандарты телесности и фиксируют пищевые девиации. Метафора информационныц фастфуд закрепила отрицательную коннотацию фастфуда, сформировавшуюся в условиях российского фронтира.

Фронтирность гастрономических практик проявляется в преодолении культурных границ в гастрономическом туризме, в соотношении высокой кухни и фастфуда - все это и разные виды дискурсивных практик, каждая из которых имеет свой набор номинаций, оценочных средств, риторических приемов. Современный человек пребывает в поиске гастрономической идентичности, показатели которой могут трансформироваться в результате движения границ физического и ментального миров.

\section{5. Фронтир и семейный дискурс}

Особенности семейного фронтира проявляются в интернациональных семьях (Бичарова 2016): транснациональная миграция приводит к формированию семьи, в которой «пограничная зона» между культурами остается если не навсегда, то на очень долгое время. Идет сложное приспособление к новой идентичности, к особенностям внутрисемейной коммуникации, традициям общения с родственниками; возникают сложности в связи с гендерной трансформацией быта, культурной социализацией детей и др.

Психологи, социологи, культурологи, лингвисты обращают внимание на поколенческий разрыв в условиях современной семьи, на то, что у каждого поколения имеется собственная дискурсивная территория. Зону интеграции в поколенческом фронтире создает общая культурная память, культивируемая в семье. Семейный дискурс как преодоление границ представлен в жанре описания семейных историй, строящихся на передающейся от поколения к поколению автобиографической памяти, способствующей совпадению межпоколенческих срезов. Прекрасный пример — монография профессора 
Л.П. Ивановой «Дискурс микросоциума (типичной семьи с типичной фамилией)», в которой описывается семейное ментальное пространство, реализуемое с помощью лингвистических средств в их широком понимании: прецедентность имен, значимых для семьи событий как общего фона знаний; роль концептов Родины, войны, родного дома, толерантности. О прививаемой в семье толерантности автор говорит так: «В аспекте толерантности подчеркну, что в нашей семье было принято идти с открытым сердцем к представителям разных стран и народов, где бы мы ни жили» (Иванова 2015: 51).

\section{3. Феномен фронтира в художественном прозаическом тексте и в поэзии}

Границе в семиосфере («внутри мыслящих миров») особое внимание уделил литературовед, культуролог и семиотик Ю.М. Лотман. Понятие границы и пограничных реалий «внутри мыслящих миров» ученый определяет как семиотическую границу. Одно из высказываний прямо проектируется на фронтирный дискурс: «Граница би-и полилингвистична. Граница - механизм перевода текстов чужой семиотики на язык «нашей», место трансформации «внешнего» во «внутреннее», это фильтрующая мембрана, которая трансформирует чужие тексты настолько, чтобы они вписывались во внутреннюю семиотику семиосферы, оставаясь, однако, инородными» (Лотман 2017: 26). Понятия «семиотическая граница личности», «семиотическая граница социума» вошли в научное пространство коммуникативистики.

Репрезентация фронтирных территорий в художественном произведении связана с категорией пространства. В художественном дискурсе существует множество моделей пространства. Обратим внимание на те, которые согласуются с фронтирными свойствами пространства в его связях с национальной историей, культурой и языком (прежде всего - в стилистических проявлениях). Концепция фронтира ориентирует на художественные модусы границы, и не случайно при описании мысленных структур пространства исследователи фронтира обращаются к способам изображения мира в романе Набокова «Дар» и к утопическому социально-философскому роману А. Платонова «Чевенгур» (Замятина 2002, 2004). Описание мифов и образов Сибири также основывается на текстах русских писателей: А. Чехова, Г. Успенского, В. Короленко, Д. Мамина-Сибиряка (Панарина 2013). Гендерная тема кавказского фронтира раскрывается с опорой на описание физического, психологического и ментального облика северокавказской женщины в произведениях русских писателей А.А. Бестужева-Марлинского, А.В. Дружинина, М.Ю. Лермонтова, Л.Н. Толстого (Манкиева 2018). [O женских персонажах на фронтире см. (Furbee 2002, Якушенко 2012)].

Художественная литература обогащает представление о пространстве, в котором есть, по правилам гуманитарной географии, пространственные мифы, знаковые места, гении места и др. Иначе говоря, художественное пространство оказывается носителем культурно-исторических смыслов и «свернутых» в пространстве ценностей и поведенческих норм. Образ пространства 
зависит от того, в пределах какой модели мира описываются события. Языковая репрезентация этапов и форм развития художественного сюжета отражает отношение к образу пространства и выявляет ментальные особенности персонажей в условиях заявленного образа. Тема «Пространство и герой» составляет особый сегмент фронтирного дискурса: образ персонажа зависит от пространственной конфигурации и формируется в границах определенного пространства, его замкнутости или открытости, сжатости или растянутости, проспективности или ретроспективности.

Фронтир проявляет исторические, социально-психологические, культурологические грани пограничья. Это касается прежде всего американской литературы. «На всем пути развития американская литература не подвергала сомнению лишь один факт, связанный с фронтиром: непреходящего значения «пограничья» в судьбе страны. В процессе ее становления состоялось самое важное открытие множества человеческих судеб, простых и часто безымянных, сделавших наследие фронтира достоянием нации, ставших материалом для вечных образов и характеров. Каждый период американской истории вносил существенный вклад в понимание феномена «пограничья», поскольку был нераздельно с ним связан» (Ващенко 1999: 374). Рассмотрение текстов американской художественной литературы с позиций фронтира представлено во множестве исследований. В числе интерпретируемых авторов - американские классики: В. Ирвинг, Ф. Купер, Х. Миллер, У. Уитмен, М. Твен, О. Генри и др. Рассматриваются сюжеты, связанные с событиями американской истории, с пограничьем, с пионерством, описанием фронтирного быта в духе жанровой разновидности романа-вестерна. Вестернизация политики и культуры - предмет особого внимания зарубежных исследователей (Kegan \& Fagen 2003). Художественная литература сохраняла цивилизационный код фронтира, способствовала утверждению американской исключительности, находчивости, свободолюбия, независимости - характеристики, которые до сих пор связываются с американской идентичностью. Сложилось понятие «люди фронтира» (фронтирмены): мужественные, честные, простые, работящие, дружелюбные, свободные, активные, легко идущие на риск, нетривиально мыслящие (Keller 2005).

В большинстве отечественных литературоведческих работ термин «фронтир» не используется. Исключение - статья «Понятие фронтира в английском литературном дискурсе» (Бондаренко, Островская 2019), в которой определяются особенности реализации и функционирования концепта «фронтир» в английском литературном дискурсе на материале романа лауреата Нобелевской премии по литературе В.С. Найпола «Полужизнь». Авторы рассматривают фронтирный дискурс как некое состояние или ситуацию, в которой могут находиться отдельные личности и целые народы. Исследование проводилось в рамках дискурс-анализа, в котором сочетались культурноисторический, концептуальный, структурный, социально-ролевой и семантический подходы. Резервы интерпретации фронтирного дискурса мы видим 
в описании категории автора и адресата, эвиденциальности (засвидетельствованности) чуждости (инаковости) в художественном нарративе, в представлении точки зрения автора и персонажей, в метаязыковых рефлексиях действующих лиц, принимающих или отвергающих чуждость, в определении функций документальных вставок, конструкций отрицания и утверждения, лексики со значением неопределенности и неожиданности и др. Описание художественного нарратива в варианте: что (кто) и кому кажется каким-то (чем-то) - имеет отношение к фронтирному дискурсу.

Фронтирный тип личности жителя Сибири (Агеев 2005) противоречив, что отражено в творчестве многих русских писателей: А. Чехова, Г. Успенского, Д. Мамина-Сибиряка и др. Сибирский характер по-русски - одно из художественных открытий В.П. Астафьева. Его герои без пафосного героизма проявляют доброту, отзывчивость, благородство, человеколюбие (Ковалева 2017). Признаки алтайского фронтира представлены в прозе В. Шукшина: деревенский уклад жизни в его противопоставлении городскому, пограничное положение маргинальный личности («странные люди»добрые и талантливые, но не умеющие приспосабливаться). Изломы личности проявляются в случае разрывов с патриархальной деревней (пространство избы и драматургия жизни вне дома). Многие особенности поэтики В. Шукшина можно отнести к художественно-языковой фиксации фронтирного дискурса: живая разговорная речь, диалектизмы, фольклорные вставки.

Фронтир прозы постмодерна имеет особые проявления. Например, в романе С. Минаева «Духless, или Повесть о ненастоящем человеке» наступившее пограничье 90-х годов представлено в виде кодовых переключений в условиях новой семиотической границы социума: названия глав и эпиграфы на русском и английском языке; цитаты из пространства Интернета, модных журналов, мультфильмов, объявлений, бухгалтерских смет, слоганов; заимствования в разном графическом оформлении и др. Очевиден процесс расширения влияния западной культуры и массовой культуры повседневности.

В художественной литературе образ границы передаётся в рефлективнодискурсивной процессуальности: граница между детством и взрослостью, любовью и потерей любви, очарованием и разочарованием, потерей родины и возвращением к ней во сне или наяву и т.д. Переход от одной «территории» жизни к другой фиксируется в стиле повествования, в характере риторических приемов и способов словопреобразования. В Тверском государственном университете прошли конференции, посвященные художественному описанию рубежей жизни в варианте между - между молодостью и зрелостью в переходе к старости. В сборниках статей «Юность как сюжет» (2018 год) и «Зрелость как сюжет» (2019 год) показана сегментация времени человеческой жизни в корреляции с эстетикой и поэтикой художественных произведений - как прозаических, так и поэтических.

В одном стихотворении А. Пушкина «Телега жизни» через образ дороги как жизненного пути соединены все возрастные этапы: утро, полдень, вечер. 
Отражение пушкинского образа жизненного пути стало поэтической традицией. Пример - стихотворение С. Маршака:

Сколько раз пытался я ускорить

Время, что несло меня вперед,

Подхлестнуть, вспугнуть его, пришпорить,

Чтобы слышать, как оно идет.

А теперь неторопливо еду,

Но зато я слышу каждый шаг,

Слышу, как дубы ведут беседу,

Как лесной ручей бежит в овраг.

Жизнь идет не медленней, но тише,

Потому что лес вечерний тих,

И прощальный шум ветвей я слышу

Без тебя - один за нас двоих.

Движение фронтира (изменение пространства и времени) проявлено в смене ритма, в переходе от глаголов совершенного вида с лексической семантикой мгновенности и интенсивности действий (подхлестнуть, всnугнуть, nришпорить) к глаголам несовершенного вида длительного действия (cльıшу, бежит, идет).

О фронтирных свойствах поэзии, появляющейся на границе миров, можно судить по творчеству многих поэтов. На важность фронтирного подхода для интерпретации творчества С. Есенина обратил внимание В. Доманский: «С. Есенин, живший на рубеже двух эпох, разломе российской цивилизации, используя эти ключевые концепты, выразил фронтирные явления российского культурного универсума. Его поэтический космос - это бытие на границе двух миров, двух Россий - Руси уходящей и России новой, советской» (Доманский 2020). Вывод исследователя о том, что, находясь в позиции фронтира, «можно увидеть, как фронтирные явления определяют поэтические дискурсы, какую функцию играют культурные коды, которые, коррелируя друг с другом, репрезентируют движение и изменение границ мира поэта», можно считать исходным тезисом для обоснования фронтирного критерия интерпретации поэзии рубежа (рубежей). Например, смена этапных диахронических срезов в творчестве А. Блока: тематика и поэтика стихотворений после революции 1905-1907 года; признание революции 1917 года; творческий кризис последних лет жизни. Новые грани видения мира - новые поэтические приемы организации стихотворных текстов.

Для поэтов характерно предчувствие рубежа в жизни страны, в собственной судьбе и творчестве. Значимым для многих поэтов оказался распад Советского Союза, в условиях которого граница между официальными и подцензурными поэтами была четко обозначена, а в 80-90-е годы нейтрализовалась. Пример - судьба и творчество В. Кривулина, у которого на переломе эпох произошло «качественное изменение поэтического языка» (Саббатини 2014). В условиях «нового зрения» происходит смена тематических 
предпочтений, стилистического регистра, меняется система цитации, более тесной становится связь поэзии с социальным контекстом.

Фронтирные показатели идиостиля И. Жданова, представителя метареализма как одного из направлений современной авангардной поэзии, связаны с синтезом двух топосов: Алтая как места рождения и Крыма, где поэт живет в настоящее время. Н.И. Завгородняя признаки метареализма поэзии И. Жданова связывает с маршрутом «Алтай - Крым», с семантикой «перехода» сквозь границу при одновременном пребывании в ней (Завгородняя 2019). «Как будто время корчится петлей / в самом себе и путает событья» - поэтическая строка И. Жданова, в которой проявлено параболическое преобразование концепта границы. Как видим, фронтир предлагает свою оптику рассмотрения художественного материала через включение синергии модуса границы в анализ жанрово-стилевой специфики художественных текстов.

\section{4. Фронтирный дискурс и проблемы маргинализации нормы}

Маргинальный (от лат. margo — край) — находящийся на границе различных социальных групп, систем, культур и испытывающий влияние противоречащих друг другу ценностей и норм; маргинализация - промежуточность, пограничность. Именно эти признаки проявляются во фронтирном дискурсе при рассмотрении его свойств в аспекте нормы.

Устойчивое равновесие необходимо для всех систем. Фронтир представляет собой неустойчивое равновесие - состояние, в котором отклонение от нормы может стать точкой перехода к новому равновесию. Большой смысл (на перспективу) заложен в таком высказывании Л.В. Щербы (1880-1944): «...я представляю себе язык находящимся все время в состоянии лишь более или менее устойчивого, а сплошь и рядом и вовсе неустойчивого равновесия, в результате действия целого ряда разнообразных факторов, зачастую друг другу противоречащих» (Щерба 2004: 50). Если отклонения от нормы единичны и активно не воспроизводятся, если соблюдается согласованность между стилем и жанром, если устная и письменная формы речи закреплены за их родными стилями, если говорящими осознается важность дихотомии «книжность/разговорность», - устойчивое равновесие нормы гарантируется. Но реальность не дает основания заменить гипотетическую (предположительную) модальность («если... то») на модальность нормативной определенности.

В гибридных жанровых образованиях, основывающихся на переходе от одной семиотической системы к другой, от одного субъекта действий к другому, проявляются свойства фронтирного дискурса. Например, телевизионный инфотейнмент («разыгрывание новости») включает саму новость с подачи ведущего как языковой (дискурсивной) личности; интервью с участниками события, которые представляет свой взгляд на новость и на ее интерпретацию журналистом; мнение эксперта, который действует в рамках институциональной нормы, что не исключает некоторых оценок события «от себя»; 
включенность в действие аудитории и др. Происходит движение фронтирных зон, сопровождающееся сменой стиля. Именно такого рода полифония не дает возможности определиться с квалификацией инфотеймента: формат, контент с синтетическим типом содержания, самостоятельная творческая единица, жанр, что свидетельствует о незавершенности и неопределенности образования, то есть о нахождении инфотейнмента на фронтирной территории. К числу фронтирных показателей можно отнести расширение границы инфотеймента от эпатажной развлекательности (information + entertainment) к применению для «разыгрывания» серьезных тем, в том числе и в печатных изданиях.

Для рассмотрения нормы сквозь призму фронтирных характеристик можно использовать понятие рамки. Неустойчивость (неопределенность) нормы особенно заметна в системе функциональных стилей, рамка каждого из которых «раздвигается» по причине вхождения иностилевых средств практически во все традиционные стили, вплоть до официально-делового. Обилие «зарамочных» фактов говорит о критическом состоянии системы. Фронтир фиксирует реперную точку перелома, сигнализирующую о том, что традиционно декларируемая целостность связей (нормативная рамка) постепенно изменяется и идет накопление новых признаков нормы на фронтирной (порубежной) территории. Частотность «зарамочных» конструкций и языковых средств, выбор которых объясняется прагматическими причинами, может свидетельствовать о накоплении новых признаков и критериев нормы.

Интердискурсивность - природное свойство фронтирного дискурса. Пограничье формируется на основе взаимодействия дискурсов: «своих» и «чужих», региональных и глобальных, устных и письменных речевых форм, конвергентных жанров (в публицистике, в художественной литературе). Фронтирный дискурс, в котором фиксируется переход от известного, нормативно закрепленного к новому, выходящему за рамки традиционных нормативных рекомендаций, демонстрирует гетерогенность большинства институциональных дискурсов и прогнозирует изменения декларируемой нормы в каждом из них (Синельникова 2019).

Тенденция к композиционным сочетаниям разных стилистических планов в одном тексте, стилистическое «расчленение» текста (В.В. Виноградов, М.В. Панов) превратилась в закономерность: властвует синтагматический принцип организации текстов разных функциональных стилей, дающий возможность реализовывать множество стилистических валентностей. Фронтирная территория в области нормы - это «место», в котором фиксируется противоречие рамки и среды. Стилисты и дискурсологи, на наш взгляд, должны совместить свои усилия по определению того, где проходит граница между правильным и неправильным, между дискурсом и текстом, между институциональными дискурсами и новыми дискурсивными практиками. Функционально-стилистическая дифференциация в литературном языке неизбежна, но перечень ее признаков может существенно измениться. 
Стандартизация знания и жесткая унификация нормы противоречат онтологии фронтира. Фронтирный дискурс базируется на нелинейных (порой кризисных) социальных процессах. Многие факты «новой нормы/не-нормы» есть смысл понимать не как отклонение от прежней (кодифицированной) нормы или естественную для развития языка вариативность, а как воплощение некой новой сущности. Расширяющееся пространство интернетжанров - тому свидетельство. Остановимся на нескольких показательных примерах. Обмен репликами в триаде «текст - отзыв - комментарий» Е.Н. Басовская соотносит с глубиной медиапространства (Басовская 2019). Движение по «ступеням» (от опубликованного текста к отзывам и комментариям), «углубляющее исходный текст как содержательно, так и стилистически», имеет очевидные признаки фронтирного дискурса: переход за границу исходного текста и создание личного пространства понимания и интерпретации на основе собственного (привычного для определенной среды) тезауруса. Приведу пример ризоматической «ветви» дискуссии, на который я обратила внимание в результате знакомства с концептом «глубина медиапространства». На интернет-форуме обсуждался научный текст о теории дискурса: Правильно говорить и писать надо векторы, а не вектора... - Ваня абсолютно не въехал в Теорию дискурса, если прилепляет к ней "перевод" Лотмана :)— Лаклау сам не въехал в "свою" теорию, как он после обнаружил :). Движение фронтиров «в глубину медиапространства» налицо.

Неопределенность квалификации многих новых коммуникативных практик, терминологический «дрейф» между жанром, форматом, методом организации коммуникации с аудиторией, особым нарративом - свидетельство пребывания на фронтирной территории. Например, популярный в Интернете жанр историй (сторителлинг) квалифицируется как гуманитарная технология, журналистская дисциплина, метод обучения. Цель сторителлинга - воздействовать на аудиторию с помощью историй, в которых реальность и вымысел могут произвольно соединяться. Специалисты (тренеры, лайф-коучи) так формулируют один из секретов эффективного сторителлинга: подстраивайте текст под конкретную аудиторию, говорите словами тех людей, которые вас слушают. Удобство общения в расчете на планируемый эффект понимания оказывается основным прагматическим фактором.

Нестандартные жанровые образования не могут не оказывать влияния на жанрово-стилистическую систему в целом. Однако мало чего можно добиться, если говорить о новых жанрах и новых дискурсивных практиках, опираясь на нормативные предписания доинтернетовской эпохи. Концепция фронтирного дискурса может способствовать переходу на новые уровни и критерии упорядоченности языкового (речевого, стилистического, жанрового) материала в новых условиях. 


\section{5. Заключение}

Междисциплинарные союзы меняют научную картину мира, особенно в случае расширения связей между гуманитарными и естественными науками. Концепция фронтира в процессе ее развития оказалась наиболее податливой для описания природных и социальных факторов в их совместности и в сопряженной динамике изменений. Фронтирные признаки: установление и движение границ, неопределенность и неустойчивость пограничья, драматургия интеграции культурных кодов - оказываются значимыми для понимания многих социально-культурных процессов.

Авторы научных работ по проблеме фронтира представляют разные области гуманитарного и естественно-научного знания. Историки, географы, философы, социологи, химики, физики, медики проявляют интерес к «пограничным» проблемам, к подвижности границ как свойству бытия - физического, территориального, культурного, языкового, ментального. Обращая внимание на кумулятивный фактор (накопление нового знания на основе имеющегося), мы стремились обозначить пространство междисциплинарной общности между дисциплинарными исследованиями через фактор границы, рубежа, пограничья. Целесообразна ориентация на концепцию фронтира в описании новых коммуникационных сред и жанрово-стилистических трансформаций в условиях «фронтирного дрейфа» в цифровом поле деятельности. Зоны фронтира обнаруживаются в социально-культурном пространстве города как динамичной структуре разного рода пограничных взаимодействий. На фронтирной территории стираются границы между массовой и элитарной культурой (прежде всего в коммуникативно-речевом измерении). В условиях «открытого мира» зону интеграции формирует гастрономический дискурс. Фронтирные показатели усматриваются в организации коммуникативного поля семейного дискурса. Перечень примеров, расширяющих концептуальную среду фронтирного дискурса, может быть продолжен. Нам важно было обратить внимание на «живые» междисциплинарные связи и обозначить потенциал их развития.

Художественные модусы границы представлены как в прозе, так и в поэзии. Фронтирные явления поэтического мира тесно связаны с пограничностью сознания лирического героя, фронтирные ситуации в прозе - с социальной действительностью, с повествовательными сегментами (пластами), обеспечивающими движение сюжета через маркировку пространственновременного и языкового (стилистического) пограничья.

Фронтир интегрируется в проблемное поле разных наук и создает возможность интерпретировать ментально-пространственные явления, находящиеся в зоне неопределенности на пути к норме. Переход через традиционные границы (рамки) наблюдается в жанрово-стилистической сфере, тесно связанной с виртуализацией общества. Именно в этой сфере происходит отказ от стилистической согласованности как традиционного параметра нормы. Структуру жанров Интернета определяют не столько кодифицированные 
стилистические нормы, сколько прагматические интенции и установка на актуальную интерактивность с целевым адресатом.

Введение понятия фронтирный дискурс позволит расширить исследовательское поле изучения гетерогенных социальных, культурных, нормативноязыковых процессов в новых конфигурациях дискурсивной среды. Представленные в статье наблюдения могут быть «развернуты» в типологическом и когнитивно-дискурсивном направлении. Одно из значений фронтира: новые возможности, открывающиеся перспективы. Многие вопросы остаются открытыми, как и остается открытым сам фронтирный дискурс, его концептуальный горизонт.

P.S. Материал статьи был собран и оформлен в «докоронавирусный» период. На наших глазах сформировался коронавирус как «незакрытый» фронтир по признакам незаконченности и неопределенности. Трансдисциплинарное описание этого уникального фронтира потребует участия ученых едва ли не всех научных профилей. Появился новый материал и для филологических наблюдений: в Сети активизировался жанр полезных советов (лайфхаков - как серьезных, так и шутливых), увеличилось количество фейковых «новостей», гибридных жанровых образований, креативных интернетмемов, пополнилась метафорическая сфера тематической группы «болезнь» и др.

С.Л.Н. Синельникова, 2020 cc)creative

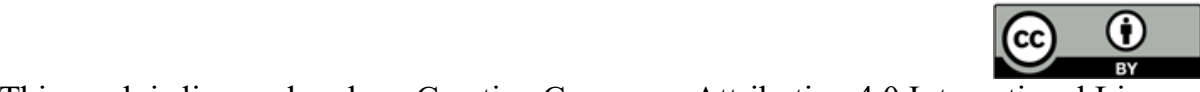

This work is licensed under a Creative Commons Attribution 4.0 International License https://creativecommons.org/licenses/by/4.0/

\section{БЛАГОДАРНОСТИ}

Автор выражает благодарность анонимным рецензентам статьи, советы и замечания которых способствовали дополнительным размышлениям над предлагаемой концепцией и способами ее представления в статье.

\section{СПИСОК ЛИТЕРАТУРЫ / REFERENCES}

Абашев В.В. Пермь как текст. Пермь в русской культуре и литературе XX века. Пермь: Издательство Пермского университета, 2000. 404 с. [Abashev, Vladimir V. 2000. Perm kak tekst. Perm v russkoy kulture i literature XX veka (Perm as text. Perm in Russian culture and literature of the XX century). Perm: Publishing House of Perm University (In Russ.)].

Агеев А.Д. Сибирь и американский Запад: движение фронтиров. М.: Аспект-Пресс, 2005. 334 c. [Ageev, Aleksandr D. 2005. Sibir' $i$ amerikanskiy Zapad: dvizhenie frontirov (Siberia and the American West: the movement of the frontier). Moscow: Aspekt-press (In Russ.)]. 
Басовская Е.Н. Дискурсивная глубина медиапространства: Текст - Отзыв - Комментарий // Ялтинский дискурсологический кружок. Результаты и перспективы совместной деятельности, 2019. С. 8-11. [Basovskaya, E.N. 2019. Diskursivnaya glubina mediaprostranstva: Tekst - Otzyv - Kommentarij. Yalta diskursologichesky circle. Results and prospects of joint activities, 8-11. (In Russ.)].

Белоконев С.Ю., Чистов И.И., Пак Джон Кван. Электронный фронтир как среда отношений бизнеса и власти // Власть. 2019. Том. 27. № 5. С. 53-58. [Belokonev, Sergey Yu., Igor I. Chistov \& Jong-Kwan Pak. 2019. Elektronnyy frontir kak sreda otnosheniy biznesa i vlasti (Electronic frontier as an environment for business and government relations). Power 27 (5). 53-58. (In Russ.)]. DOI: https://doi.org/10.31171/ vlast.v27i5.6719.

Бичарова М.М. Интернациональная семья как микромодель фронтира и проблемы культурной безопасности // Журнал фронтирных исследований. 2016. № 1. С. 90—99. [Bicharova, Mariya M. 2016. Internacional'naya sem'ya kak mikromodel' frontira i problemy kul'turnoj bezopasnosti (International family as a micromodel of the frontier and issues of cultural safety). Journal of frontier research 1. 90 — 99. (In Russ.)].

Бондаренко Л.В., Островская Т.А. Понятие фронтира в английском литературном дискурсе // Лингвистика будущего: новые тенденции и перспективы. Майкоп, 2019. C. 115-118. [Bondraenko, Lyudmila V. \& Tatiana A. Ostrovskaya. 2019. Ponyatie frontira $\mathrm{v}$ anglijskom literaturnom diskurse (The concept of frontier in English literary discourse). Linguistics of the future: new trends and prospects, 115-118. Maykop. (In Russ.)].

Бостан К.А., Кузнецов А.М. Идея «фронтира»: выгодное приобретение или опасный «фантом»? // Ойкумена. Регионоведческие исследования. 2018. № 1. С. 73-84. [Bostan, Kseniya A. \& Anatoliy M. Kuznetsov. 2018. Ideya «frontira»: vygodnoye priobreteniye ili opasnyy «fantom»? (The idea of "frontier": a profitable acquisition or a dangerous "phantom"?). Oykumena. Regional researches 1. 73-84. (In Russ.)]. DOI: 10.24866/1998-6785/2018-1/73-84.

Ващенко А.В. Фронтир // История литературы США: М., 1999. Т. 2. С. 349-375. [Vashchenko, Aleksandr V. 1999. Frontir (Frontier). Istoriya literatury SSHA, 2. 349375. Moscow. (In Russ.)].

Гринько И.А. «Музейные границы» и формирование новых идентичностей // Самарский научный вестник. 2016. № 4 (17). C. 149-152. [Grin’ko, Ivan A. 2016. «Muzeynyye granitsy» i formirovaniye novykh identichnostey («Museum borders» and the formation of new identities). Samarskij nauchnyj vestnik 4 (17), 149—152. (In Russ.)].

Довбыш Е.Г. Электронный фронтир как метафора // Журнал фронтирных исследований. 2016. № 1. C. 100 - 115. [Dovbysh, Evgeniy G. 2016. Elektronnyj frontir kak metafora (Electronic frontier as a metaphor). Journal of Frontier Studies 1. 100-115. (In Russ.)].

Доманский В. Тема «фронтира» в художественно-публицистических дискурсах C.A. Есенина [Domansky, Valeriy. Tema «frontira» v hudozhestvenno-publicisticheskih diskursah S.A. Esenina (The theme of the "frontier" in the artistic and journalistic discourses of S.A. Yesenin). URL: http://www.osrussia.ru/content/tema-frontira-vhudozhestvennopublicisticheskih-diskursah-s-esenina (дата обращения: 27.03.2020). (In Russ.)].

Забияко А.П. Порубежье как данность человеческого бытия // Вопросы философии. 2016. № 11. C. 26-36. [Zabiyako, Andrey P. 2016. Porubezh'e kak dannost' chelovecheskogo bytiya (Frontier as a Reality of Human Existence). Voprosy Filosofii 11. 26-36. (In Russ.)].

Завгородняя Н.И. Берег как предгорье (художественная топонимика Алтая и Крыма в текстах И. Жданова // Культура и текст. 2019. № 3 (38). С. 98 -106. [Zavgorodnyaya, 
Natalia I. 2019. Bereg kak predgor'e (hudozhestvennaya toponimika Altaya i Kryma v tekstah I. Zhdanova) (The shore as a piedmont (artistic toponymy of Altai and Crimea in the texts of I. Zhdanov). Kul'tura i tekst 3 (38). 98-106. (In Russ.)].

Замятин Д.Н. Гуманитарная география: пространство, воображение и взаимодействие современных гуманитарных наук // Социологическое обозрение. 2010. Т. 9. № 3. C. 26-50. [Zamyatin, Dmitriy N. 2010. Gumanitarnaya geografiya: prostranstvo, voobrazhenie i vzaimodejstvie sovremennyh gumanitarnyh nauk (Humanitarian geography: space, imagination and interaction of modern humanities). Sociological review 9 (3). 26-50. (In Russ.)].

Замятина Н.Ю. Художественная литература как материал для изучения мысленных структур пространства (на примере романа В. Набокова «Дар») // География искусства. Вып. 3. 2002. С. 92-106. [Zamyatina, Nadezhda Yu. 2002. Hudozhestvennaya literatura kak material dlya izucheniya myslennyh struktur prostranstva (na primere romana V. Nabokova «Dar») (Fiction as a material for the study of the mental structures of space (example of The Gift of Nabokov). Geography of art 3. 92-106. (In Russ.)].

Замятина Н.Ю. Локализация идеологии в пространстве (американский фронтир и пространство в романе А. Платонова «Чевенгур») // Гуманитарная география: Научный и культурно-просветительский альманах. 2004. Вып. 1. С. 53-61. [Zamyatina, Nadezhda Yu. 2004. Lokalizaciya ideologii v prostranstve (amerikanskij frontir i prostranstvo v romane A. Platonova «Chevengur») (Localization of ideology in space (American frontier and space in A. Platonov's novel Chevengur). Humanitarian geography: Scientific and cultural and educational almanac 1.53-61. (In Russ.)].

Замятина Н.Ю. Норильск - город фронтира // Вестник Евразии. 2007. № 1. С. 167-192. [Zamyatina, Nadezhda Yu. 2007. Norilsk - gorod frontira (Norilsk - city of the frontier). Bulletin of Eurasia 1. 167-192. (In Russ.)].

Иванова Л.П. Дискурс микросоциума (типичной семьи с типичной фамилией). Киев: Освита Украины, 2015. 64 с. [Ivanova, Lyudmila P. 2015. Diskurs mikrosociuma (tipichnoj sem'i s tipichnoj familiej) (Discourse of microsocium (typical family with a typical surname)). Kiev: Osvita Ukrainy. (In Russ.)].

Карабущенко П.Л. Элита и фронтир // Журнал фронтирных исследований. 2016. № 2. C. 92 -104. [Karabushenko, Pavel L. 2016. Elita i frontier (Elite and frontier). Journal of Frontier Studies 2. 92-104. (In Russ.)].

Киселева M.C. Гуманитарные исследования и проективность: дисциплинарные и междисциплинарные стратегии знания // Ученые записки Казанского университета. Серия Гуманитарные науки. 2016. Т. 158. Кн. 4. С. 1163-1172. [Kiseleva, Marina S. 2016. Gumanitarnyye issledovaniya i proyektivnost': distsiplinarnyye i mezhdistsiplinarnyye strategii znaniya (Humanitarian research and projectivity: disciplinary and interdisciplinary knowledge strategies). Uchenyye zapiski Kazanskogo universiteta. Seriya Gumanitarnyye nauki 158 (4). 1163-1172. (In Russ.)].

Ковалева А.М. Сибирский характер в книге «Царь-рыба» В.П. Астафьева как модификация русского национального характера // Вестник Красноярского государственного педагогического университета им. В.П. Астафьева. 2017. № 2 (40). С. 208-212. [Kovaleva, Anna M. 2017. Sibirskij harakter v knige «Car'-ryba» V.P. Astaf'eva kak modifikaciya Russkogo nacional'nogo haraktera (Siberian character in the book tsar ryba by V.P. Astafiev as a modification of the Russian national character). Bulletin of Krasnoyarsk State Pedagogical University named after V.P. Astafiev 2 (40). 208-212. (In Russ.)].

Лотман Ю.М. «Внутри мыслящих миров»// Развитие личности. 2017. № 1. С. 13-59. [Lotman, Yuriy M. 2017. Vnutri myslyashchih mirov ("Inside the Thinking Worlds"). Personal Development 1. 13-59. (In Russ.)]. 
Манкиева Э.Х. Русская «кавказоведческая» проза XIX в.: гендерный дискурс // Филологические науки. Вопросы теории и практики. Тамбов: Грамота. 2018. № 6 (84). Ч. 1. C. 23-28. [Mankieva, Eset Kh. 2018. Russkaya «kavkazovedcheskaya» proza XIX v.: gendernyj diskurs (Russian "Caucasian" prose of the 19th century: gender discourse). Philological sciences. Theory and practice issues. 6 (84). 1. 23-28. (In Russ.)].

Морозова Е.В., Мирошниченко И.В., Рябченко Н.А. Фронтир сетевого общества // Мировая экономика и международные отношения. 2016. Т. 60. № 2. С. 83-97. [Morozova, Elena V., Inna V. Miroshnichenko \& Natalia A. Ryabchenko. 2016. Frontir setevogo obshchestva (The Frontier of Network Society). World economy and international relations. 60 (2). 83-97. (In Russ.)].

Олянич А.В. Презентационная теория дискурса: монография. Волгоград: Парадигма, 2004. 507 c. [Olyanich, Andrey. 2004. Prezentatsionnaya teoriya diskursa (Presentation theory of discourse). Volgograd: Paradigm. (In Russ.)].

Островская Т.А. Исследование дискурса элиты в синергетической парадигме // ДискурсПи. Научный журнал. 2016. № 3-4 (24-25). С. 85-91. [Ostrovskaya, Tatiana A. 2016. Issledovanie diskursa elity v sinergeticheskoj paradigm (Researches of the Elite Discourse in the Synergetic Paradigm). Discourse Pi. Scientific magazine $3-4(24-25)$. 85-91. (In Russ.)].

Панарина Д.С. Мифы и образы сибирского фронтира // Культурная и гуманитарная география. 2013. Т. 2. № 1. С. 39-52. [Panarina, Daria S. 2013. Mify i obrazy sibirskogo frontira (Myths and images of the Siberian frontier). Journal of Frontier Studies 2 (1). 39-52. (In Russ.)].

Плотичкина Н.В. Герои сетевого фронтира // Журнал фронтирных исследований. 2017. № 4 (8). C. 110 - 126. [Plotichkina, Natalia V. 2017. Geroi setevogo frontira (Heroes of the Network Frontier). Journal of Front Studies 4 (8). 110-126. (In Russ.)].

Плотичкина Н.В. Мифология электронного фронтира // Вестник Нижегородского университета им. Н.И. Лобачевского. Серия: Социальные науки. 2018. № 1 (49). С. 80 88. [Plotichkin, Natalia V. 2018. Mifologiya elektronnogo frontira (Mythology of the electronic frontier). Journal of the Nizhny Novgorod University named after N.I. Lobachevsky. Series: Social Sciences 1 (49). 80-88. (In Russ.)].

Поволоцкий А. Фонд Электронного Фронтира [Povolockij, Aleksandr. Fond Elektronnogo Frontira (Electronic Frontier Foundation). URL: https://bugtraq.ru/library/misc/eff.html/ Fond Elektronnogo Frontira (дата обращения: 24.03.2020). (In Russ.)].

Романова А.П. Современный мегаполис как фронтирная гетеротопия // Ученые записки Крымского федерального университета имени В.И. Вернадского. Философия. Политология. Культурология. 2016. Том 2 (68). № 3. С. 51-60. [Romanova, Anna P. 2016. Sovremennyy megapolis kak frontirnaya geterotopiya (Modern megapolis as a frontier heterotopia). Scientific Notes of V.I. Vernadsky Crimean Federal University. Philosophy. Political science. Culturology 2 (68). 3. 51-60. (In Russ.)].

Саббатини М. Виктор Кривулин на переломе эпох. Заметки о смене поэтики во второй половине 1980-х годов // Вестник СПбГУ. Серия 9. 2014. Вып. 4. С. 44-50. [Sabbatini, Marko. 2014. Viktor Krivulin na perelome epoh. Zametki o smene poetiki vo vtoroj polovine 1980-h godov (Victor Krivulin at the turn of the century. Notes on the change of poetics in the second half of the 1980s). St. Petersburg State University Herald 9 (4). 44-50. (In Russ.)].

Синельникова Л.Н. Медийная коммуникация в проекции на современную теорию фронтира // Настоящее и будущее стилистики. М.: ФЛИНТА, 2019. С. 654-659. [Sinel'nikova, Lara N. 2019. Medijnaya kommunikaciya v proekcii na sovremennuyu teoriyu frontira (Media communication in projection on modern frontier theory). The present and future of style, 654-659. Moscow: FLINTA. (In Russ.)]. 
Сиротинина О.Б. Борьба с рискогенностью общения как одна из проблем речеведения // Проблемы речевой коммуникации. 2014. №1. С. 5-14. [Sirotinina, Olga В. 2014. Bor'ba s riskogennost'yu obshheniya kak odna iz problem rechevedeniya (Fighting with riskogenics of communication as one of the problems of conversational speech study). Problems of Speech Communication 1. 5-14. (In Russ.)].

Сохань И.В. Трансформации современной гастрономической культуры и тоталитет фастфуда. СПб.: НОРМА, 2014. 230 с. [Sohan', Irina V. 2014. Transformacii sovremennoj gastronomicheskoj kul'tury i totalitet fastfuda (Transformation of modern gastronomic culture and fast food totality). St. Petersburg: NORMA. (In Russ.)].

Тернер Ф. Дж. Фронтир в американской истории. М.: Весь мир, 2009. 304 с. [Terner, Frederik Dzh. 2009. Frontir v amerikanskoj istorii (The Frontier in American History). Moscow: Ves' mir. (In Russ.)].

Тузовский И.Д. Интернет - территория «фронтира» информационного общества // Федерализм. 2009. № 4. С. 229-236. [Tuzovsky, Ivan D. 2009. Internet - territoriya "frontira" informatsionnogo obshchestva (Internet-territory of the "frontier" of information society). Federalism 4. 229-236. (In Russ.)].

Ulrich P., Троицкий С. Сложность «границ»: постановка проблемы, терминология и классификация // Журнал фронтирных исследований. 2019. № 4 (2). С. 234 -256. [Ulrich, Peter \& Sergey Troitskiy. 2019. Slozhnost «granits»: postanovka problem, terminologiya i klassifikatsiya (The complexity of «borders»: research Agendas, terminology and classification). Zhurnal frontirnykh issledovaniy 4 (2). 234-256. (In Russ.)]. DOI: 10.24411/2500-0225-2019-10035.

Шляховой Д.А. Жанровые характеристики блогов как электронных средств массовой коммуникации // Вестник Российского университета дружбы народов. Серия: Теория языка. Семиотика. Семантика. 2017. Т. 8. № 4. С. 939-948. [Shlyakhovoy, Dmitriy A. 2017. Genre characteristics of blogs as electronic media (Genre features of blogs as electronic means of mass communication). RUDN Journal of Language Studies, Semiotics and Semantics 8 (4). 939-948. (In Russ.)]. DOI: 10.22363/2313-2299-2017-84-939-948.

Щерба Л.В. Очередные проблемы языковедения // Щерба Л.В. Языковая система и речевая деятельность. М.: Едиториал УРСС, 2004. С. 39-50. [Shcherba, Lev V. 2004. Ocherednye problemy yazykovedeniya (Another problem of linguistics). Language system and speech activities, 39-50. Moscow: Editorial URSS. (In Russ.)].

Яковлева Е.Л. Фронтирность гастрономических повседневных практик // Журнал фронтирных исследований. 2018. № 1. С. 7-15. [Yakovleva, Elena L. 2018. Frontirnost' gastronomicheskih povsednevnyh praktik (Frontierism of gastronomic everyday practices). Journal of frontier research 1. 7-15. (In Russ.)].

Якушенков С.H. "In Frontier We Trust" // Журнал фронтирных исследований. 2019. № 3 (15). C. 12-59. [Yakushenkov, Sergey N. 2019. Journal of frontier research 3 (15). 12-59. (In Russ.)]. DOI:10.24411/2500-0225-2019-10018.

Якушенкова О.С. Женщина на американском фронтире. Астрахань: Сорокин Роман Васильевич, 2012. 221 с. [Yakushenkova, O.S. 2012. Zhenshchina na amerikanskom frontire. Astrahan': Sorokin Roman Vasil'evich. (In Russ.)].

Billington, Ray A. \& Martin Ridge. 1982. Westward Expansion. A History of the American Frontier. New York.

Faragher, John M. 2006. The Myth of the Frontier: Progress or Lost Freedom. The American West, 9. The Gilder Lehrman Institute of American History.

Febvre, Lucien. 1973. Frontier: The Word and the Concept. In Burke, P. (eds.), A New Kind of History from the Writings of Lucien Febvre, 208-218. London: Routledge. 
Fernandez-Armesto, Felipe. 2009. Near a Thousand Tables: A History of Food. New York: The Free Press.

Furbee, Mary R. 2002. Outrageous Women of the American Frontier. New York: John Wiley $\&$ Sons.

Hall, Thomas. 2009. Puzzles in the Comparative Study of Frontiers: Problems, Some Solutions, and Methodological Implications. American Sociological Association XV (1). DOI: 10.5195/jwsr.2009.332

Herring, Susan \& John Paolillo. 2006. Gender and Genre Variation in Weblogs. Journal of Sociolinguistics 10 (4). 439-459. DOI: 10.1111/j.1467-9841.2006.00287.

Kegan, Paul \& Herb Fagen. 2003. The Encyclopedia of Westerns. N.Y.: Checkmark Books.

Keller, Alexandra. 2005. Historical Discourse and American Identity in Westerns since the Reagan Era. Hollywood's West: The American Frontier in Film, Television and Histor, 239-260. Lexington: The University Press of Kentucky.

Turner, Frederick J. 1921. The Frontier in American History. NY: Holt.

Wrangham, Richard. 2009. Catching Fire: How Cooking Made Us Human. New York: Basic Books.

\section{Article history:}

Received: 17 March 2020

Revised: 28 March 2020

Accepted: 14 April2020

\section{История статьи:}

Дата поступления в редакцию: 17 марта 2020

Дата принятия к печати: 14 апреля 2020

\section{Сведения об авторе:}

ЛАРА НИКОЛАЕВНА СИНЕЛЬНИКОВА - доктор филологических наук, профессор кафедры русской и украинской филологии с методикой преподавания Гуманитарно-педагогической академии - филиала Крымского федерального университета в г. Ялте. Сфера научных интересов: дискурсология, когнитивистика, стилистика, риторика, лингвополитология, лингвистическая поэтика, паблик рилейшнз. Основные научные публикации: Жизнь текста, или Текст жизни: избранные работы в 3-х томах (2005), Дискурсивная семантика русских местоимений. Коммуникативные сценарии в прозе и в поэзии: монография (2013), Стихотворный текст: междисциплинарная интерпретация: монография (2019), а также разделы в коллективных монографиях, изданных в России, Белоруссии, Польше. Член редакционных советов научных журналов «Мир лингвистики и коммуникации», «Современный дискурсанализ».

\section{Контактная информация:}

Крымский федеральный университет имени В.И. Вернадского в г. Ялте 298635, Россия, Ялта, ул. Севастопольская, 2-а

e-mail: prof.sinelnikova@gmail.com

ORCID ID: https://orcid.org/0000-0001-8140-5648 


\section{Bionote:}

LARA N. SINELNIKOVA, PhD, Professor at the Department of Russian and Ukrainian Philology, and methods of teaching in the Academy of Humanities and Pedagogics, the branch of the Crimean Federal University in Yalta. The fields of scholarly interests: discourse analysis, cognitive linguistics, stylistics, rhetoric, linguapolitology, linguistic poetics, and public relations. Major publications: Life of the Text, or the Text of Life: Selected Works in 3 Volumes (2005), Discursive Semantics of Russian Pronouns, Communicative scripts in prose and poetry (a monograph, 2013), Poetic text: interdisciplinary interpretation (a monograph, 2019), as well as chapters in co-authored monographs published in Russia, Belarus, and Poland. Member of the editorial boards of scholarly journals: World of Linguistics and Communication and Modern DiscourseAnalysis.

\section{Contact information:}

Academy of Humanities and Pedagogics (branch) of Vernadsky Crimean Federal University in Yalta

2-a, Sevastopolskaya str., Yalta, 29863, Russia

e-mail: prof.sinelnikova@gmail.com

ORCID ID: https://orcid.org/0000-0001-8140-5648 